ment Boards, which are constituted by the medical officers of health and the hospital directors.

\section{Medical Socheties.}

The new law which fixes the responsibility of the doctor for his work more exactly than was the case before, has brought about the foundation of a corporation whose object is to protect its members against lawsuits. The body is still very young and its working capacity has not yet been demonotrated to the public. But it may be mentioned that actions for alleged or actual damages by medical intervention are very rare among us.

Social Position.

Taking all in all the position of a practitioner in Austria is not very bad, though it cannot compare, with a limited number of exceptions, with the position of his English or French confreres. The social position, however. is not lower than anywhere else. The overcrowding in the capital naturally makes it more hard and difficult to obtain the proper standard of estimation, but even here a man is thought as much as he is personally worth. If anywhere, so it is in our profession, that \& man must stand for himself. If only the material aspects were better no doubt only the better classes would put their sons into the profession. Quite a number of doctors and professors have received the knighthood or a baronetcy; in the Parliament we have about fifteen members of our profession. The names of many doctors can be read amongst the most distinguished men, and wherever a private or public undertaking for social and political work is formed, one or two doctors are sure to be asked to join it. I might add that the leaders of some of our numerous political parties are, or have been, active practitioners.

\section{HUNGARY.}

By Gustav Dintenfass, M.D., Vienna.

Hungary, being a part of the empire of Austria-Hungary, is, ss far as medical matters are concerned, subject to the same laws as Austria ; only the grievances are a little more pronounced, and less effort is made to remedy them. The candidate for the profession has to pass an examination comprising Latin, Greek, mathematics, geography, physics, and history. Then he enters a university. Of these there are only two, one in the capital, one on the eastern frontier. This naturally tends to centralization of the medical teaching, and the Government is always willing, for political reasons, to strengthen the position of the university in Buda-Pesth, so as to weaken the other institution.

Professional Study and Graduation.

The course of study, which lasts five years, comprises all the branches of the science and art of healing. The examinations are not severe. They are three in number: the "State examinations" or Rigorosum, and a few minor ones of little importance. The student may take up any course he likes first, but for military reasons must finish before his 28 th year. When he has passed his last Rigorosum he is admitted to the degree of Universae Medicinae Doctor. There are no intermediate diplomas. The few holders of old diplomas, who styled themselves M.B. or Ch.B., are dying out fast, so that within a few years there will be no practitioners who are not Doctors of Medicine. As regards the university teachers and lecturers, there are two degrees, the first corresponding to the German and English professor, and the second to the German Privat-docent or lecturer on a certain branch of the medical studies. They are also the examiners for the diploma; both are paid by the Government, and receive besides a certain amont in examination fees. It must be borne in mind that in Hungary the Government alone keeps up the universities, and thus exercises its influence upon all medical teaching. Therefore the lecturers are paid, not as in Austria, where the Privat-docent is really a private lecturer. This is perhaps the only difference in university administration between the two closely-allied countries.

The standard of life, to which the young doctor is generally accustomed, is that of the lower middle class. The popuIation finding its chief occupation in agriculture and pasture, the business class is not very numerous except in the towns, and from the latter the practitioners mostly come. Lately the industrial element has been coming to the front, but the sons of well-to-do tradesmen, higher factory officials, and Civil Service employes form the bulk of the medical students, whilst the so-called gentry or nobility turns with scarcely an exception to the study of law. As the cost of medical study is comparatively low, the expense can be met without too much effort on the part of the student's family, and his requirements are not of a very luxurious kind. It may be taken for granted that $f 60$ a year will cover all the expense of living in one of the two university cities, whilst the fees for lectures, examinations, registration and special courses in surgery, and laryngoscopy, together with the cost of the diploma, are easily covered by another $€ 80$. Thus a capital of $£ 400$ is enough to "make a doctor."

Rights and Dutiks of Practitionkrs.

If the young doctor wishes to begin to practise he merely is required to announce his intention to the local magistrate. His obligations towards the public are the same as anywhere else. He is not asked to work for nothing, but is bound to answer any call, unless there is a reasonable ground for refusal. He is responsible for what he does in that he may be sued in cases of gross neglect; otherwise he is left a free hand to act according to the best of his knowledge and ability. His duties towards the State are also not very onerous. The signing of death certificates, the notification of cases of infectious disease, do not take up too much of his time. For all other medical functions there are specially-appointed medical officers, whose duty towards the State is strictly defined. Most country practitioners not only have their private practice, but are also medical officers of health, paid by the State. They thus combine several more or less well-paid appointments, and are at once private doctors and public. unctionaries.

By law every district of a certain area must have a medical officer who has to be paid by the State. For the benefit of the profession several districts are combined into one comitat, or large district, for which a chief divisional medical officer and two subordinate offic rs are appointed. They have to share the work of the district doctor. There are several thousands of such divisions, each extending over an area of 26 to 40 square miles, and offe ing good prospects for medical men. The pay is small, being only $f 36$ a year for the district doctor and about $£ 120$ for the head officer. It must, however, be taken into account that $£ 30$ in Hungary will go further than $£ 90$ in England.

Professional Earnings.

The average receipts of a middle-class practitioner in the country amount to $£ 200$ or $f 300$ a year, and this sum is mostly sufficient to enable him to lead a tolerably comfortable life and to save something for his old age. As there is no fixed scale of fees he may charge any reasonable amount. The ordinary charges are a shilling or two for a consultation. in his office, sometimes even double that amount; at least 28 . for a visit, with increased pay if he has to travel overland a mile or so. The country people are very slow to call in a doctor, but once he is called they do not spare the money, and take a pride in rewarding his skill. After all, the money is not too hardly earned in rich districts. The case is altogether different in the poor mountainous comitats where the people have to labour hard for their daily bread. There froo must suffice; more cannot be made, and the doctor must turn to agriculture or take up some other calling in addition to his profession. Not seldom they come after many years to own large estates simply by combination of profession and business. In the towns, of which there are not many with more than 50,000 inhabitants, the practitioner has no easy position. The competition is not very keen, but prices are low, on account of the system of yearly payments of a fixed sum from a family. They pay as much as $£ 4$ to $£ 8$ a year, for which all members of the household have to receive medical attendance! On the other hand, the fee for a visit in a strange family is hardly more than $2 \mathrm{~s}$. Taking all in all, the income of a town doctor is not more than $£ 300$, rather less, and his expenditure is higher than that of his colleague in the country. Friendly Societies' clubs, which employ medical men at a fixed fee, are not very numerous ; still they are somewhat tyrannical, as there is no organization among the medical associations. There are several men in every town who have something like a consulting practice, mostly the senior surgeon and senior physician of the hospital. They hardly ever possess the title of Privat-docent or professor, and in addition to consultations they keep up a general practice. Hungary is hardly ripe for specialization. These practitioners get better 
fees, even as much as a pound sterling for a consultation. Their income is generally a good one, amounting even to $f 600$ to $£ 800$ a year. In particular the surgeons are comparatively well paid, $£$ 10 to $£ 30$ being a not infrequent fee for a difficult operation. Of course in the capital, where the university is, and where there are over half a million inhabitants, things are altogether different. The general practitioner may charge from 28. to 58. for a visit, and if he has a good reputation he may charge double the amount. His average income is hardly under $£ 300$, and the professors and Docenten, who are really specialists and have generally consulting practices, earn as much as $f 1,000$ a year or more. Still a fee of more than $f_{1}$ los. is even for a professor a rarity. Some are said to earn as much as $£ \mathrm{I}, 000$ a year, but this is only a legend.

\section{StatistiCs.}

The total number of medical men in Hungary at the last census accessible to me (1903) was 6,800 for a population of about 19 millions, which works out at an average of 1 in 2,800 . This figure must be corrected for the larger towns. Whilst Buda-Pesth, with its university and its hospitals, shows a proportion of $I$ in 850 to $I$ in 700 , other towns like Klausenburg, Sopron, Szegedin Fiume have a ratio of from $I$ in $I, 200$ to $I$ in 1,600 . In the flat country, where villages of 2,000 or 3,000 inhabitants are very numerous, with perhaps only one practitioner, the ratio is still more favourable, as these village are many miles distant from each other. Thus there is no overcrowding in the profession, but there is also no large influx into it on account of the moderate prospects it offers. In spite of the scarcity of hospitals and charitable institutions, quite a number of patients cannot be counted on from the point of view of medical practice, as the population is rather unintelligent, and calls the doctor only when the necessity for doing so is urgent. On the other hand, the district doctor has to treat gratuitously all the poor of the district and the abuse of his position is enormous, with but little possibility of improvement in the existing state of affairs.

The Profission and the Law.

The relation between the profession and the service of justice may be touched upon briefly. Naturally, medical experts are required in suitable cases, such as murder and insanity. Nobody can be sent to an asylum or deprived of his lawful and material rights unless after examination by a specially-appointed medical commission, which reports to the judge. The tariff for expert reports is low, not so much as a guines a day, and only 28. 6d. for each sheet of paper in written reports.

Unqualifikd Practich.

Turning to quackery and illegal practice, it may be said of Hungary that it is a veritable land of promise for that sort of business. The few medical organizations have scarcely any influence, and the vast stretches of flat country inhabited by a population of little or no education form a happy hunting ground for all sorts of healers and herbalists, bonesetters, and nostrum-vendors, who wander about from place to place to look up their customers. In the cities now and then a magnetizer or an old woman is credited with the gift of supernatural diagnosis and healing, and the law concerns itself little about them, because they cannot be brought to court unless somebody complains of having been permanently injured by their practices. The text of the law is to the following effect

Whosoever practises the art of healing publicly, without being duly qualified by his studies and without a licence from a university, or applies narcotic medicines, other, chloroform, shall be guilty of an offence, and, according to the length of time he has been infringing this law, he shall be punished by imprisonment from one to six weeks. If the death of a person is the result of such practice the punishment may be increased from one to five y9ars. Midwives especially are cautioned against undertaking manipulations within the body of the mother before the child is born.

The regulations, however, are rather imperfect. Thus, the law requires publicity of the nffence; it does not state anything about the necessity for the intervention of the magistrate, even without complaints being lodged; and practitioner are not always eager to take cases into court. Moreover, the law is not very strictly applied, and not uniformly throughout the country. In the west the effects of European civilization demand up.to-date proceedings; in the east and gouth the magistrates, whose duty it should be to punish such breaches of the law, are more lenient.: Only when there has been gross neglect and bad mistakes have been committed do they refrain from shutting their eyes to the proceedings of quacks. Patent medicines are not abundant, as the industry is not well developed, and drugs and medicines can be hact only from apothecaries or the country doctors. Each " nostrum" must show in its name its action, and its constituente must not be kept secret.

Contract Mrdiche Practice.

Clubs, Friendly Societies, and other combinations for securing medical aid at reduced prices are not numerous, except in the towns and industrial places, and they pay only moderately-hardly more than $f 40$ a year. But a pleasant, not ill-paid appointment is that of a family doctor to the very numerous gentry and lower and higher grades of nobility. The pay is perhaps $£ 30$, but the number of people. to be looked after is small-40 to 50 at the utmost. Appointments to insurance companies are also very much sought after, as they pay 8s. for each examination, and more in proportion for any special report. These figures contrast. favourably with the pay received for medical attendance on workhouses, Government factories, railway companies, and collieries. As has already been said, the sum of $f 300$ earned by a practitioner in the country is partly derived from such appointments, and it is not a high proportion that comes from fixed sources.

Protection of Profegsional Inthrests.

For the defence of the interests of the profession there is in each county or Comitat an association of the local practitioners, but there is no central council. The medica department of the Ministry of the Interior is controlled by a doctor, but he has no right to interfere with the private associations, and a good many laws and regulations are passed after consultation with the Buda-Pesth Faculty alone. Funds for the widows and orphans, for mutual aid in court, for the sick members of the profession there are none, and only feeble attempts to unite the different county Boards have been made. So weak is the organization that even advertising by a few medical men, which is commonly regarded here as a breach of medical etiquette, cannot be stopped. Needless to say, the provident arrangements for the members of the profession are not very important. There are $a$ few insurance companies which offer certain advantages to the relatives of diseased practitioners, but that is about all. Naturally, owing to the influence of Western principles, the ideas of organization and provision for old age are getting a firm hold on the members of the profession, but they are still only in their infancy.

\section{Mrdical Practice by Forhigners.}

As regards foreign diplomas there is but little difficulty in obtaining the venia practicandi. The applicant is required to pass an examination in the Hungarian language, and also in materia medica, as the Hungarian Pharmacopoeia differs materially from that of other countries. Otherwise the examinations in medical matters which are required of Hungarian candidates are not very severe, and a diploma of, say Paris or Berlin, is a good passport. There are as yet nc. diplomas in medicine for ladies; the few attempts on the part. of the League of Emancipation of Women to obtain for their clients admission to the hospital wards and dissecting rooms have, so far, proved fruitless.

Social Position.

The social position of a doctor is, take it all round, not. particularly good, but it is not so bad as might be supposed from the facts above stated. People still are accustomed to see in him, especially in the country, a representative of knowledge and duty, and hold him in no less esteem than the local judge or any other magistrate. They sometimes even honour him so much as to elect him for Parliament. Amongst 380 members of the Lower House five seats are held by members of the profession, all of whom belong to the Liberal or Progressive Party.

\section{ITALY.}

By F. H. Burton-Brown, M.A., M.D., Late Physician, British Embassy, Rome.

Education and Qualification to Practise.

THE only qualification recognized by the law in Italy for Italian medical men consists in the degree of M.D., which is granted by seventeen Royal Universities and the Royal Institate of Florence. 